відповідальність як умова саморозвитку особистості в освіті / А. А. Кравченко // Нова парадигма : [журнал наук. праць] / гол. ред. В.П.Бех; Нац. пед. ун-т імені М. П. Драгоманова; творче об’єднання «Нова парадигма». - Вип. 114. - Київ : Вид-во НПУ імені М. П. Драгоманова, 2013. - С. 42-50. 3. Куниця Т. Ю. Виховання відповідальної поведінки в учнів 7-8-х класів загальноосвітньої школи : автореф. дис. ... канд. пед. наук : 13.00.07 - теорія і методика виховання / Куниця Тетяна Юріївна. - Київ, 2008. - 23 с. 4. Левківський М. В. Критерії та рівні розвитку відповідального ставлення до праці / М. В. Левківський // Рідна школа. - 1993. - № 11-12. - С. 54-56. 5. Панченко Т. В. Принцип субсидіарності в сучасному демократичному розвитку: [монографія] / Т. В. Панченко.Харків : Майдан, 2011. - 361 с. 6. Пономарьов О. С. Відповідальність в системі професійної компетентності фахівця : [навч.-метод, посіб.] / О.С. Пономарьов, М. К. Чеботарьов. Харків : Підручник НТУ «ХПІ», 2012. - 220 с. 7. Рижанова А. О. Розвиток соціальної суб'єктності та принцип субсидіарності соціально-педагогічної діяльності / А. О. Рижанова // Педагогіка та психологія: [зб. наук. праць]/ за заг. ред. академіка I. Ф. Прокопенка, проф. С. Т. Золотухіної. - Харків : Вид-во ТОВ «Щедра садиба плюс», 2015. - Вип.48.260 с. 8. Субсидіарність // Соціальна робота. Короткий енциклопедичний словник. - Київ : ДЦССМ, 2002. - Кн. 4. - С. 460. 9. Федорченко Т. Є. Соціально-педагогічні засади профілактики девіантної поведінки школярів в умовах соціокультурного середовища : дис... доктора пед. наук : спец. 13.00.05; Держ. заклад «Луган. нац. ун-т ім.. Тараса Шевченка» / Тетяна Євгенівна Федорченко. - Луганськ, 2013. - 561 с.

\title{
ВПЛИВ КОМУНІКАТИВНОГО ТА ТРАДИЦЙНИХ МЕТОДІВ НАВЧАННЯ ІНОЗЕМНОЇ МОВИ В ПОЧАТКОВІЙ ШКОЛІ НА СТАНОВЛЕННЯ ТВОРЧОЇ ОСОБИСТОСТІ МОЛОДШОГО ШКОЛЯРА
}

Васильєва О. В. Вплив комунікативного та традиційних методів навчання іноземної мови в початковій школі на становлення творчої особистості молодшого школяра.

Стаття присвячена аналізу ролі традиційних методів навчання іноземної мови та висвітлює позитивні й негативні аспекти використання комунікативного методу в початковій школі. Автор аналізує провідні методики, що застосовуються для формування комунікативної компетентності молодших школярів.

Ключові слова: комунікативна компетентність, комунікативний метод, традиційні методи, початкова школа, молодші школярі.

Васильева О. В. Влияние коммуникативного и традиционного методов обучения иностранному языку в начальной школе на становление творческой личности младшего школьника.

Статья посвящена анализу традиционных методов и коммуникативного подхода в процессе преподавания иностранного языка в начальной школе, обозначены позитивные и негативные аспекты использования коммуникативного метода в начальной школе. Автор анализирует ведущие методики, которые используются для формирования коммуникативной компетентности младших школьников.

Ключевые слова: коммуникативная компетентность, коммуникативный метод, традиционные методы, начальная школа, младшие школьники. 
Vasylieva O. V. Influence of communicative and traditional methods of foreign language teaching at primary schools on the creative personality development of a primary school pupils.

The article deals with the analysis of traditional methods and communicative approach in the process of foreign language teaching at primary schools. The advantages and disadvantages of communicative method are shown. The author analyzes the major methods used to form the communicative competence of primary school pupils.

Key words: communicative competency, communicative method, traditional methods, primary schools, primary school pupils.

Розбудова української держави, інтеграція до Європейського і Світового співтовариства, перехід до високотехнологічного інформаційного суспільства вимагають подальшого переосмислення змісту, методів, форм організації мовної освіти, зокрема в початковій школі. Створення нових ефективних моделей шкільного навчання мови має спрямовуватися на виховання особистості, яка здатна до самоосвіти і саморозвитку, вміє швидко опрацьовувати здобуту інформацію, використовувати набуті знання і вміння для творчого розв'язання проблем, вільно орієнтуватися в різноманітних комунікативних ситуаціях. Усе це вимагає комплексного застосування як вербальних, так і невербальних засобів задля комунікації, уміння спілкуватися в конкретних соціально-побутових ситуаціях, виявляти ініціативність під час спілкування, вільно користуючись усною і писемною формами мовлення. Проблема ефективної організації мовленнєвої діяльності, спрямованої на оволодіння усним і писемним мовленням, постає сьогодні ще з більшою гостротою і у зв'язку з подальшою розробкою iї теоретичних основ у комунікативній лінгвістиці, теорії тексту, функціональній стилістиці, психології, психолінгвістиці й лінгводидактиці, підвищенням вимог до результатів навчального процесу з рідної та іноземної мови.

Актуальність дослідження зумовлена необхідністю вдосконалення процесу навчання мови і мовлення, новими науковими досягненнями в комунікативній лінгвістиці, теорії тексту, функціональній стилістиці, психології, психолінгвістиці й лінгводидактиці, запити педагогічної науки створюють об'єктивну потребу осмислення концептуальних засад формування комунікативної компетентності молодших школярів.

Метою статmі є аналіз переваг та недоліків комунікативного методу викладання англійської мови порівняно з традиційними, виявлення специфіки роботи саме в початковій ланці освіти.

Аналіз лінгводидактичної літератури свідчить, що проблема формування культури мовлення школярів на сучасному етапі $є$ надзвичайно актуальною. Науковці О. Біляєв, Л. Варзацька, М. Вашуленко, І. Гудзик, Т. Донченко, С. Караман, В. Мельничайко, М. Пентилюк, О. Савченко, М. Сокирко, розробляючи шляхи оновлення змісту й структури системи мовної освіти, вважають, що вся робота 3 розвитку зв'язного мовлення має спиратися на понятійні знання учнів, екстралінгвістичні умови й операційні. Ретроспективний аналіз методичної літератури свідчить, що надзвичайно поширеним протягом останніх 40 років уважається комунікативний метод викладання іноземної мови [3, c. 25].

Традиційні підходи в навчанні мови віддавали пріоритет формуванню граматичної компетенції як основи володіння мовою. Вони були засновані на переконанні, що граматику можна засвоїти шляхом прямого навчання й за методикою, що спиралась на багаторазове використання практичних вправ. Підхід до викладання граматики був дедуктивний: учням представляли правила граматики, а потім надавали можливість практикуватися, на відміну 
від індуктивного підходу, в якому учні отримують зразки речень, що містять правила граматики, і просять їх розробити правила для себе. Передбачалося, що вивчення мови означає створення великого репертуару речень та граматичних конструкцій і вироблення вміння використовувати їх точно й швидко у відповідній ситуації. Як тільки основні команди мови було засвоєно на основі усних вправ, контролю, чотири види діяльності, як правило, вводились у такій послідовності: говоріння, аудіювання, читання, письмо.

Методи, які часто використовувались, включали запам'ятовування діалогів, питань та відповідей, вправи на заміну, передбачали усну та письмову практику. Велика увага до точної вимови й граматичної правильності приділялась $з$ початкового етапу вивчення мови.

Методики, засновані на цих припущеннях, включають аудіолінгвізм (у Північній Америці) (також відомий як усний метод), а також структурно-ситуаційний підхід у Великобританії (також відомий як ситуаційний). Навчальні програми традиційно складались зі списків слів і граматики, відсортовані за рівнями.

На типовому аудіолінгвальному уроці, як правило, виконуються такі завдання: 1. Учні вперше слухають зразок діалогу, що містить ключові структури, які знаходяться в центрі уваги уроку. Вони повторюють кожен рядок діалогу, індивідуально й хором. Учитель звертає увагу на вимову, інтонацію та вимову. Виправлення помилок у вимові та граматиці є прямим і безпосереднім. Діалог запам'ятовується поступово, рядок за рядком. Діалог читають уголос хором, одна половина класу повторює репліку першого мовця, а інша відповідає. 2. Діалог адаптується до інтересу учнів або ситуації, шляхом зміни певних ключових слів або фраз. Все розігрується учнями. 3. Деякі ключові структури 3 діалогу вибираються i використовуються як основа для зразків різних видів вправ. Можуть даватись деякі граматичні пояснення. 4. Учні можуть звернутися до підручника для подальшого читання, письма або словникової роботи.

На звичайному уроці, відповідно до ситуаційного підходу, існувала трифазна послідовність, відома як цикл ППВ: презентація, практика, відтворення. Структура уроку ППВ широко представлена в матеріалах викладання іноземних мов i продовжує у видозміненій формі використовуватися нині. Багато усного мовлення або граматики $\epsilon$ основою уроків у сучасній методиці [1, с. 34].

Під впливом теорії комунікативного викладання мови граматично-обгрунтовані методики, такі, як ППВ, поступилися навчанню функціональному, заснованому на життєвих навичках, і необхідність таких заходів, як вправи і граматична практика, були замінені під впливом діяльності, заснованої на інтерактивній роботі в малих групах. Це призвело до того, що у 1970-х почалася й швидко поширилася по всьому світу реакція на традиційні підходи викладання мов, на такі методи, як аудіолінгвізм і ситуативний підхід, що стали неактуальними. Центральна роль граматики у викладанні мови та навчанні була поставлена під сумнів, оскільки було відзначено, що мовна компетентність передбачає значно більше, ніж формування граматичної компетенції. Хоча граматична компетенція необхідна для відтворення граматично правильних речень, увага зміщується до знань і навичок, необхідних для використання граматики та інших аспектів мови відповідно для різних комунікативних завдань, таких, як прохання, надання поради, внесення пропозицій, опис побажання i потреби тощо. Необхідним для використання мови стало формування комунікативної компетенції. Це більш широке поняття, ніж граматична компетенція, і містить знання про те, що сказати і як сказати доречніше, виходячи із ситуації, учасників, їх ролей і намірів. Недоліком традиційних підходів $є$ те, що навчальні програми і методи навчання граматики й лексики не передбачають такої інформації. Уважалося, що цей вид знання мав набуватись 
неформально.

Під час планування мовних курсів в рамках комунікативного підходу, граматика вже не була відправною точкою. Були необхідні нові підходи до викладання мови. Замість того, щоб просто проаналізувати граматику і словниковий запас учнів, що необхідно засвоїти, було відзначено, що програма має враховувати певні аспекти використання мови, щоб мати можливість розвивати спілкування учня, формувати комунікативну компетенцію: 1. Для учнів, які бажають вивчити мову, зазначено конкретну можливу мету, наприклад, використання англійської мови для подорожей. 2. Певне уявлення про ситуації, у яких вони хочуть використовувати мову, наприклад, в магазині. 3. Соціальне визначення певної ролі учнів у мові, що вивчається, а також роль співрозмовників, наприклад, мандрівник, продавець розмовляє 3 клієнтами, учень у школі. 4. Комунікативні завдання, у яких учні можуть брати участь: повсякденні ситуації, телефонні дзвінки, участь у неформальному спілкуванні, участь у засіданні гуртків. 5. Для реалізації мовленнєвих функцій використовують завдання, у яких учень буде в змозі за допомогою мови, наприклад, представитись, дати пояснення або описати плани. 6. Поняття або концепції, за допомогою яких учень буде в змозі говорити про відпочинок, історію тощо. 7. Різноманітність варіантів мови, які будуть необхідні, наприклад, американський, австралійський або британський, рівнів усної та писемної мови, яких учні повинні досягти. 8. Необхідний граматичний, лексичний зміст та словниковий запас.

Основними перевагами комунікативного методу є органічне поєднання свідомих i підсвідомих компонентів у процесі навчання іноземної мови, тобто засвоєння правил оперування іншомовними моделями відбувається одночасно 3 оволодінням їх комунікативно-мовленнєвою функцією.

Комунікативний підхід найбільшою мірою відбиває специфіку іноземної мови на початковому етапі навчання. Цей метод визначився в результаті методичного осмислення наукових досягнень у галузі лінгвістики - теорії комунікативної лінгвістики і психології та теорії діяльності, що знайшло відображення в роботах з психології та методики навчання іноземних мов (О. Леонтьєв, І. Зимня, Ю. Пассов, С. Шатілов, Г. Рогова та ін.). Реалізація комунікативного підходу в навчальному процесі з іноземної мови означає, що формування іншомовних мовленнєвих навичок і вмінь відбувається шляхом і завдяки здійсненню учнем іншомовної мовленнєвої діяльності. Засвоєння засобів спілкування спрямоване на їх практичне застосування у процесі спілкування. Оволодіння уміннями говоріння, аудіювання, читання та письма здійснюється шляхом реалізації цих видів мовленнєвої діяльності у процесі навчання в умовах, що моделюють ситуації реального спілкування [4, с. 121-125].

Сучасне комунікативне викладання мови спирається на цілу низку різних освітніх парадигм i традицій, немає єдиного узгодженого набору практик, які характеризують поточне комунікативне навчання мови. Комунікативне навчання мови нині спирається на загальноприйняті принципи, які можуть застосовуватися по-різному, залежно від контексту навчання, віку учнів, їх рівня, цілей навчання.

Основними надбаннями та позитивними змінами в методиці викладання англійської мови в початковій школі завдяки реалізації комунікативного методу можна вважати: 1. Автономність учня: надання вибору щодо власного навчання, як 3 точки зору змісту навчання у початкових класах, так і процесів, які вони можуть здійснювати. 2. Соціальний характер навчання: навчання не окрема, приватна діяльність, а соціальне явище, яке залежить від взаємодії з іншими людьми. 3. Навчальні інтеграції: підкреслюється зв'язок між різними напрямами навчальної програми, отже, англійська мова не розглядається як окремий 
предмет, а пов'язана з іншими предметами навчального плану. 4. Акцент на спрямування: змістовність розглядається як рушійна сила пізнання. 5. Індивідувальність: учні вчаться порізному і мають різні сильні сторони, ураховуються індивідуальні особливості учнів. 6. Особливості мисленнєвої діяльності: мова має служити засобом розвитку навичок критичного i творчого мислення. 7. Альтернативна оцінка: множинні форми оцінки (наприклад, спостереження, інтерв'ю, щоденники, портфоліо). 8. Творча співпраця вчителя й учнів: учитель розглядається як посередник, який постійно перевіряє різні альтернативи, тобто навчання відбувається через дію.

Отже, значна перевага комунікативного методу у становленні творчої особистості молодшого школяра полягає в тому, що процес навчання англійської мови будується адекватно реальному процесу мовленнєвого спілкування, тобто процес навчання $є$ моделлю процесу мовленнєвої комунікації. На жаль, процес навчання не може повністю збігатися 3 процесом комунікації, який має місце в реальному житті, оскільки навчання англійської мови в навчальних закладах відбувається в умовах рідномовного оточення. Тому йдеться тільки про максимальне зближення процесів навчання i реального спілкування за такими найважливішими параметрами, як комунікативно-вмотивована мовленнєва поведінка вчителя та учнів і предметність процесу спілкування. Недоліком комунікативного методу можна вважати недостатню увагу до формування граматичної компетентності учнів, оскільки наявна основна спрямованість на вдосконалення швидкості мовлення учнів та здатності висловлювати власні думки. Навчальна програма 3 іноземної мови в початковій школі передбачає використання різноманітних методів, але чітка організація дій учнів 3 навчальним матеріалом, оснащення навчального процесу необхідними засобами, що стимулюють і забезпечують розв'язання конкретних завдань, можуть вести до досягнення комунікативної мети і служити надійною основою для становлення творчої особистості у процесі навчання англійської мови на початковому етапі. Перспективою подальшої роботи $\epsilon$ створення експериментальної моделі формування комунікативної компетентності учнів початкових класів на уроках мови.

\section{Література}

1. Бадер В. Удосконалення мовленнєвого розвитку молодших школярів / В. Бадер // Педагогіка і психологія. - 1998. - № 4. - С. 31-36. 2. Барановська Л. В. До теоретичних засад формування культури мовлення / Л. В. Барановська // Педагогіка і психологія. - 1997. № 3. - С. 33-37. 3. Гаркуша В. В. Формирование навыков общения и коммуникативных способностей в процессе личностно-ориентированного обучения устной иноязычной речи : дис. на соискание ученой степени канд. психол. наук / Гаркуша В. В. - Днепропетровск, 1992. - 129 с. 4. Зимняя И. А. Психология обучения иностранным языкам в школе/ И. А. Зимняя. - Москва : Просвещение, 1991. - 222 с. 5. Richards J. Commuticative teaching today / J. Richards. - Cambridge, 2006. -42 p.

\section{ФОРМУВАННЯ ЕКОЛОГІЧНОГО СВІТОГЛЯДУ МАЙБУТНІХ УЧИТЕЛІВ ПОЧАТКОВОЇ ШКОЛИ У ПРОЦЕСІ ПРОФЕСІЙНОЇ ПІДГОТОВКИ}

Грошовенко О. П. Формування екологічного світогляду майбутніх учителів початкової школи у процесі професійної підготовки.

У статті актуалізується необхідність посилення гуманістичного складника системи 